\title{
USAGE AND LONG-TERM COMPLICATIONS OF VOICE PROSTHESIS IN PATIENTS WITH TOTAL LARYNGECTOMY - OUR APPROACH TO PERIPROSTHETIC LEAKAGE
}

\author{
MARIJA PASTORČIĆ GRGIĆ, PAVAO PERŠE, BORIS STUBLJAR and SANDRA DOKO
}

Department of Head and Neck Surgery, Division of Surgical Oncology, University Hospital for Tumors, Sestre milosrdnice University Hospital Center, Zagreb, Croatia

\section{Summary}

Aim: To determine success in use of voice prosthesis, prosthesis lifetime and long-term complications after total laryngectomy with primary tracheoesophageal puncture and to describe our approach to periprosthetic leakage.

Introduction: Voice restoration after total laryngectomy is usually performed by placing a silicone voice prosthesis in an artificially formed tracheoesophageal fistula.

Methods: We performed a retrospective study on 187 laryngectomies with primary tracheoesophageal puncture in the 15-year period, treated in our hospital.

Results: In the group of patients with more than 1 year follow up, $87.8 \%$ of patients had successful voice restoration. Average prosthesis lifetime was 8 months. Long-term complications developed in $17.5 \%$ of patients. Periprosthetic leakage was the most common. We were able to successfully resolve long-term complications in 19/24 patients and they continued to use their vocal prostheses.

Conclusion: The primary placement of the voice prosthesis is successful and safe way to restore a voice after a total laryngectomy. Complications are commonly treatable in an outpatient clinic or with minor surgery.

KEYWORDS: total laryngectomy, voice prosthesis, periprosthetic leakage

\section{INTRODUCTION}

Primary prosthetic voice restoration at the time of surgery is the standard of care in patients treated with total laryngectomy for advanced laryngeal or hypopharyngeal cancer(1). Traheoesophageal puncture (TEP) can be performed at initial surgery (primary TEP) or after initial surgery (secondary TEP). Primary TEP is considered a safe and efficient approach for voice rehabilitation $(2,3)$. According to some authors secondary

Corresponding author: M. Pastorčić Grgić, Department of Head and Neck Surgery, University Hospital for Tumors, Sestre milosrdnice University Hospital Center Ilica 197, 10000 Zagreb, Croatia.e-mail: marija_pastgrgic@yahoo.com
TEP should be preferred when there is a higher risk of pharyngocutaneous fistula $(4,5)$.

Although TEP with voice prosthesis placement has improved voice rehabilitation, the procedure may be associated with complications both at the time of placement and later(6). The incidence of complications is higher for patients who required salvage total laryngectomy after chemoradiotherapy or radiotherapy than in patients initially treated surgically(7).

There are several types of prostheses available worldwide. Two types are the most widely used, and both of them are used in Croatia ad well: Provox prosthesis - I, II and the VEGA (Atos Medical, Hörby, Sweden) and the Blom-Singer prosthesis (Inhealth Technologies, Carpinteria, 
CA, USA). Successful voice restoration is achieved in $75-85 \%$ of patients $(8,9)$. Different prostheses comparisons did not identify a best prosthesis, but patients have personal preferences(10).

Voice prosthesis is a one way valve, preventing entrance of fluids from esophagus to trachea, and allowing airflow from trachea to esophagus. One of the major drawbacks of voice prostheses is limited device lifetime. Expected prosthesis lifetime is 3 to 9 months. Due to the deterioration of the silicone material by biofilm formation, prostheses either leak or increase airflow resistance(11). Valve failure can interfere with respiration, swallowing and speech. Internal prosthetic leakage may result in aspiration pneumonia and dehydration, and repeated valve replacement may lead to either tracheoesophageal fistula stenosis or insufficiency(12). Prevention and control of biofilm formation are crucial for the lifespan of the prosthe$\operatorname{sis}(13)$.

The other frequent problem in patients with voice prosthesis is periprosthetic leakage. It develops in up to $30 \%$ of patients(14-16). Depending on the severity of fistula enlargement, treatment ranges from conservative approaches to invasive procedures(14-16).

\section{PATIENTS AND METHODS}

This is a retrospective study that included patients surgically treated from 2005 to 2019 at University Hospital for Tumors. Data was collected from our database. All patients who received total laryngectomy with primary TEP for advanced laryngeal or hypopharyngeal cancer were included. Patients lost from follow-up within first year after surgery were excluded.

The demographic data, use of voice prosthesis, prosthesis lifetime and long-term complications were collected and analyzed.

This is a single institution experience. During 15 year-period 10 ENT surgeons were educated to perform TEP, replace prosthesis and take care of complications. In cases of major periprosthetic leakage at least two trained ENT surgeons are involved in selection of appropriate treatment.

Prosthesis was routinely replaced when leakage through the prosthesis or acquired inability to speak were found.

Periprosthetic leakage was classified as minor or major. Leakage was considered minor in cases when it was resolved in one outpatient visit. Leakage was considered major and a long-term complication when it could not be resolved in one outpatient visit.

Minor periprosthetic leakage is assessed and appropriate procedure performed:

a) inappropriate prosthesis size - replacing prosthesis with appropriate size prosthesis (usually downsizing)

b) minor fistula widening - replacing prosthesis with custom prosthesis (large esophageal or tracheal flange, or both)

c) minor granulation tissue - excision of granulation tissue and replacing prosthesis with appropriate size prosthesis (usually downsizing) Supportive measure is oral protein pump inhibitor therapy during 1-2 weeks.

In cases of major periprosthetic leakage, conservative approach is implemented first:

1) prosthesis removal and nasogastric tube placement

2) in cases of excessive granulation tissue - cutting off or silver nitrate cautery

3) daily monitoring of fistula size - when adequate diameter reduction is observed - placing appropriate size prosthesis or custom prosthesis

In cases of unsuccessful conservative treatment:

a) persistent granulation - $\mathrm{CO}_{2}$ laser ablation and placing appropriate size prosthesis

b) fistula widening -multiple layers suture of tracheoesophageal fistula

c) fistula closure - secondary TEP

Major periprosthetic leakage is treated during short hospital stay. $\mathrm{CO}_{2}$ laser ablation and secondary TEP are performed under short intravenous anesthesia. Multiple layers suture of tracheoesophageal fistula can be done in short intravenous anesthesia or local anesthesia. Supportive measures include parenteral protein pump inhibitor therapy during hospital stay and sometimes antibiotic therapy. Protein pump inhibitor therapy is continued orally for 1-2 months.

We used descriptive statistical methods.

\section{RESULTS}

In the 15-year period a total number of 187 laryngectomies with primary TEP were performed. The results are presented in Table 1. 
Table 1.

Data summary.

\begin{tabular}{|l|l|l|l|}
\hline \multicolumn{2}{|l|}{} & TOTAL \\
\hline \multirow{2}{*}{ FOLLOW UP } & $>12$ months & $<12$ months & \multirow{2}{*}{187} \\
\cline { 2 - 4 } & $156(83.4 \%)$ & $31(16.6 \%)$ & \\
\hline \multirow{2}{*}{ VOICE RESTORATION } & SUCCESSFUL & UNSUCCESSFUL & \multirow{2}{*}{156} \\
\cline { 2 - 4 } & $137(87.8 \%)$ & $19(12.2 \%)$ & \multirow{2}{*}{137} \\
\hline \multirow{2}{*}{ LONG-TERM COMPLICATIONS } & WITHOUT & WITH & \\
\cline { 2 - 3 } & $113(82.5 \%)$ & $24(17.5 \%)$ & \\
\hline
\end{tabular}

Table 2.

Causes and treatment of major periprosthetic leakage. All patients were initially treated conservatively, and surgical treatment was done only if conservative treatment was not successful.

\begin{tabular}{|c|c|c|c|c|c|c|}
\hline & \multicolumn{3}{|c|}{ CONSERVATIVE TREATMENT } & \multicolumn{3}{|c|}{ SURGICAL TREATMENT } \\
\hline $\begin{array}{l}\text { CAUSE OF } \\
\text { PERIPROSTHETIC } \\
\text { LEAKAGE } \\
\end{array}$ & $\begin{array}{l}\text { NUMBER OF } \\
\text { PATIENTS }\end{array}$ & & $\begin{array}{l}\text { RATE OF } \\
\text { SUCCESS }\end{array}$ & $\begin{array}{l}\text { NUMBER OF } \\
\text { PATIENTS }\end{array}$ & & $\begin{array}{l}\text { RATE OF } \\
\text { SUCCESS }\end{array}$ \\
\hline GRANULATIONS & 11 & $\begin{array}{c}\text { EXCISION + } \\
\text { PROSTHESIS } \\
\text { REMOVAL AND NG } \\
\text { TUBE }\end{array}$ & $6 / 11$ & 5 & CO2 LASER & $4 / 5$ \\
\hline WIDE FISTULA & 6 & $\begin{array}{c}\text { PROSTHESIS } \\
\text { REMOVAL AND NG } \\
\text { TUBE }\end{array}$ & $3 / 6$ & 3 & $\begin{array}{l}\text { MULTIPLE LAYERS } \\
\text { SUTURE +/- } \\
\text { SECONDARY TEP }\end{array}$ & $2 / 3$ \\
\hline $\begin{array}{l}\text { MISSING } \\
\text { PROSTHESIS }\end{array}$ & 4 & $\begin{array}{l}\text { PATENT FISTULA } \\
\text { - PROSTHESIS } \\
\text { PLACEMENT }\end{array}$ & $2 / 4$ & 2 & $\begin{array}{l}\text { CLOSED FISTULA } \\
\text { - SECONDARY TEP }\end{array}$ & $2 / 2$ \\
\hline TOTAL & 21 & & $11 / 21$ & 10 & & $8 / 10$ \\
\hline
\end{tabular}

During the first year $31(16.6 \%)$ patients were lost from follow-up.

In the group of $156(83.4 \%)$ patients average follow up was 55 (12-174) months. The mean age was $62.2(42-84)$ years. There were $138(88.5 \%)$ male and $18(11,5 \%)$ female patients.

In this group of patients $137(87.8 \%)$ were successful in using the prostheses, and 19 (12.2\%) never achieved voice restoration. In the group of patients who never achieved voice restoration all patients were males.

Further analysis was performed in the group of 137 patients who were successfully using voice prostheses. During the study period 1192 prostheses (in total) were replaced according to indications described. The average prosthesis lifetime was 8 months.

In $113(82.5 \%)$ patients the use of voice prosthesis went without any complications. Long-term complications were observed in $24(17.5 \%)$ patients.
Periprosthetic leakage developed in 21 patients (Table 2). According to clinical records excessive granulation tissue around the prosthesis was described in 13 patients, a wide fistula in 4 patients and 4 patients came after noticing a missing prosthesis. All patients were initially treated conservatively. $\mathrm{CO}_{2}$ laser ablation was performed in 5 patients. Minor surgery (multiple layers suture of tracheoesophageal fistula) was performed in 3 patients. Secondary TEP was performed in 3 patients. Two $(2 / 21)$ patients from this group stopped using the prosthesis.

Two patients developed a second primary tumor and after a second surgery ( 1 and 6 years after the first surgery) stopped using the prosthesis.

One patient developed fibrosis of the tracheoesophageal fistula and stopped using the prosthesis after 9 years.

Overall, we were able to successfully resolve long-term complications in 19 (19/24) patients and they continued to use their vocal prostheses. 


\section{DISCUSSION}

Voice rehabilitation after total laryngectomy is achieved by primary TEP and voice prosthesis placement in majority of cases.

Demographic data in our study show that majority of patients are males between 60 and 70 years of age what is similar to series described in literature(14-16).

According to the literature successful voice restoration is achieved in $75-95 \%$ of patients $(8$, $9,15)$. In our series it was almost $88 \%$.

Prosthesis lifetime was 8 months which is near to the upper limit of expected prosthesis lifetime - 3 to 9 months(15).

Periprosthetic leakage is clinically recognized as a significant complication of tracheoesophageal voice restoration, however there is no consensus regarding the frequency of its occurrence, risk factors or management(14). It is considered as a long-term complication with mean time to fistula enlargement estimated between 20 and 40 months(14).

Periprosthetic leakage develops in up to $30 \%$ of patients(14-16). We have found long-term complications in $17.5 \%$ of patients, and majority (21/24) was periprosthetic leakage.

Periprosthetic leakage can be clinically presented in several ways. In our study patients were presented with excessive granulation tissue formation around prosthesis or with widening of the fistula or they were complaining of missing the prosthesis. In the latter group fistula can be patent or not. Based on clinicians finding the individual treatment is selected. A variety in presentation implies that single approach is not successful for all patients. At the moment, there is no sufficient data to determine an evidence-based algorithmic model of management(14).

Conservative treatments applied include: adjusting prosthesis length, removing granulation tissue, use of customized prosthesis with a large esophageal and/or tracheal flange and removal of the prosthesis with placement of a nasogastric tube. In patients without prosthesis and with patent fistula, placement of prosthesis can be done in outpatient setting.

Periprosthetic leakage may occur as the result of improper length of the prosthesis in the absence of TEP enlargement(14). Op de Coul et al. reported $57 \%$ success rate of prosthesis downsiz- ing(17). Several authors reported $80-100 \%$ success rates of customized prostheses(16). Removal of the prosthesis with placement of a nasogastric tube is widely accepted approach. Reduction of the fistula diameter is expected after 7 to 14 days. Reported success of this approach is about $50 \%$, and it can lead to a complete closure of the fistula(16). Other methods described are tissue augmentation, botulinum toxin injections, anti-reflux medications and proton pump inhibitors $(16,18)$.

In a small proportion of patients revision surgery is indicated. Indications include several unsuccessful attempts to resolve the problem or very wide fistula at follow-up visit. In our series minor revision surgery included removing granulation tissue with $\mathrm{CO}_{2}$ laser, multiple layers suture of tracheoesophageal fistula or secondary TEP.

The literature shows that cautery silver nitrate, electrocautery and $\mathrm{CO}_{2}$ LASER are used to treat granulation tissue around the prosthesis(19). Multiple layers suture is technique described in small series with success rates of $50-70 \%(16)$. Following the closure of a tracheoesophageal fistula, a secondary TEP can be performed and a new voice prosthesis can be inserted after 3-4 months. Other described techniques include purse-string suture, interposition of local or distant flap(16).

In our series we were able to successfully resolve long-term complications in 19/24 patients and they continued to use their vocal prostheses. The majority of patients with periprosthetic leakage can be managed with minimally or moderately invasive procedures.

\section{REFERENCES}

1. Tawfik GM, Makram OM, Zayan AH, Ghozy S, Eid PS, Mahmoud MH, et al.Voice Rehabilitation by Voice Prostheses After Total Laryngectomy: A systematic review and network meta-analysis for 11,918 Patients. J Speech Lang Hear Res. 2021 Jul 16;64(7):2668-2681. doi: 10.1044/2021_JSLHR-20-00597.

2. Robinson RA, Simms VA, Ward EC, Barnhart MK, Chandler SJ, Smee RI. Total laryngectomy with primary tracheoesophageal puncture: Intraoperative versus delayed voice prosthesis placement. Head Neck. 2017 Jun;39(6):1138-1144. doi: 10.1002/hed.24727.

3. Luu K, Chang BA, Valenzuela D, Anderson D. Primary versus secondary tracheoesophageal puncture for voice rehabilitation in laryngectomy patients: A systematic review. Clin Otolaryngol. 2018 Oct;43(5):12501259. doi: 10.1111/coa.13138. 
4. Barauna Neto JC, Dedivitis RA, Aires FT, Pfann RZ, Matos LL, Cernea CR. Comparison between primary and secondary tracheoesophageal puncture prosthesis: A systematic review. ORL J Otorhinolaryngol Relat Spec. 2017;79(4):222-229. doi: 10.1159/000477970.

5. Chakravarty PD, McMurran AEL, Banigo A, Shakeel M, Ah-See KW. Primary versus secondary tracheoesophageal puncture: systematic review and metaanalysis. J Laryngol Otol. 2018 Jan;132(1):14-21. doi: 10.1017/S0022215117002390.

6. Tong JY, Pasick LJ, Benito DA, Sataloff RT. Complications associated with tracheoesophageal voice prostheses from 2010 to 2020: A MAUDE study. Am J Otolaryngol. 2020 Nov-Dec;41(6):102652. doi: 10.1016/j. amjoto.2020.102652.

7. Starmer HM, Ishman SL, Flint PW, Bhatti NI, Richmon J, Koch W, et al. Complications that affect postlaryngectomy voice restoration: primary surgery vs salvage surgery. Arch Otolaryngol Head Neck Surg. 2009 Nov;135(11):1165-9. doi: 10.1001/archoto.2009.168.

8. Mäkitie AA, Niemensivu R, Juvas A, Aaltonen LM, Bäck L, Lehtonen H. Postlaryngectomy voice restoration using a voice prosthesis: a single institution's tenyear experience. Ann Otol Rhinol Laryngol. 2003 Dec;112(12):1007-10. doi: 10.1177/000348940311201202.

9. Bozec A, Poissonnet G, Chamorey E, Demard F, Santini J, Peyrade F, et al. Results of vocal rehabilitation using tracheoesophageal voice prosthesis after total laryngectomy and their predictive factors. Eur Arch Otorhinolaryngol. 2010 May;267(5):751-8. doi: 10.1007/ s00405-009-1138-x.

10. Coffey MM, Tolley N, Howard D, Hickson M. Evaluating the effect of different voice prostheses on alaryngeal voice quality. Laryngoscope. 2018 Nov;128(11): 2460-2466. doi: 10.1002/lary.27171.

11. Sayed SI, Datta S, Deore N, Kazi RA, Jagade MV. Prevention of voice prosthesis biofilms: current scenario and future trends in prolonging prosthesis lifetime. J Indian Med Assoc. 2012 Mar;110(3):175-8, 180.
12. Talpaert MJ, Balfour A, Stevens S, Baker M, Muhlschlegel FA, Gourlay CW. Candida biofilm formation on voice prostheses. J Med Microbiol. 2015 Mar;64(Pt 3):199-208. doi: 10.1099/jmm.0.078717-0.

13. Leonhard M, Schneider-Stickler B. Voice prostheses, microbial colonization and biofilm formation. Adv Exp Med Biol. 2015;830:123-36. doi: 10.1007/978-3-31911038-7_8.

14. Hutcheson KA, Lewin JS, Sturgis EM, Kapadia A, Risser J. Enlarged tracheoesophageal puncture after total laryngectomy: a systematic review and metaanalysis. Head Neck. 2011 Jan;33(1):20-30. doi: 10.1002/ hed.21399.

15. Lorenz KJ. The development and treatment of periprosthetic leakage after prosthetic voice restoration. A literature review and personal experience part I: the development of periprosthetic leakage. Eur Arch Otorhinolaryngol. 2015 Mar;272(3):641-59. doi: 10.1007/ s00405-014-3394-7.

16. Lorenz KJ. The development and treatment of periprosthetic leakage after prosthetic voice restoration: a literature review and personal experience. Part II: conservative and surgical management. Eur Arch Otorhinolaryngol. 2015 Mar;272(3):661-72. doi: 10.1007/ s00405-014-3393-8.

17. Op De Coul BM, Hilgers FJ, Balm AJ et al. A decade of postlaryngectomy vocal rehabilitation in 318 patients: a single Institution's experience with consistent application of Provox indwelling voice prostheses. Arch Otolaryngol Head Neck Surg 2000;26:1320-1328

18. Danic Hadzibegovic A, Kozmar A, Hadzibegovic I, Prgomet D, Danic D. Influence of proton pump inhibitor therapy on occurrence of voice prosthesis complications. Eur Arch Otorhinolaryngol. 2020 Apr;277(4): 1177-1184. doi: 10.1007/s00405-020-05784-4.

19. Smith WK, Pfleiderer AG. The use of the KTP laser in the management of hypertrophic tracheal mucosa and granulation tissue around Provox valve protheses. J Laryngol Otol. 2003 Jan;117(1):60-2. doi: 10.1258/0022 21503321046667. 


\section{Sažetak \\ UPOTREBA I ODGOĐENE KOMPLIKACIJE NAKON UGRADNJE GOVORNE PROTEZE KOD LARINGEKTOMIRANIH BOLESNIKA - NAŠ PRISTUP RJEŠAVANJU CURENJA UZ PROTEZU}

\section{Pastorčić Grgić, P. Perše, B. Stubljar, S. Doko}

Cilj rada je analizirati uspješnost korištenja govornih proteza, životni vijek proteza kao i odgođene komplikacije kod primarne ugradnje govorne proteze nakon totalne laringektomije kao i opisati naš pristup rješavanju curenja uz protezu.

Uvod: Govorna rehabilitacija nakon totalne laringektomije se najčešće postiže ugradnjom silikonske govorne proteze $\mathrm{u}$ umjetno formiranu treheoezofagealnu fistulu.

Metode: retrospektivno smo analizirali 187 bolesnika koji su u 15-godišnjem periodu liječeni u našoj bolnici te kod kojih je učinjena primarna ugradnja govorne proteze nakon totalne laringektomije.

Rezultati: U grupi bolesnika koji su postoperativno praćeni više od godine dana, $87,7 \%$ je zadovoljavajuće govorno rehabilitirano. Prosječno trajanje govorne proteze je bilo 8 mjeseci. Odgođene komplikacije je razvilo 17,5\% bolesnika. Najčešća komplikacija je bila curenje uz govornu protezu. Uspješno smo riješili odgođene komplikacije kod 19 od 24 bolesnika koji su se nakon toga nastavili služiti govornom protezom.

Zaključak: Primarna ugradnja govone proteze je uspješan i siguran način postizanja govorne rehabilitacije nakon totalne laringektomije. Komplikacije nakon postupka je najčešće moguće rješiti već prilikom ambulantnog pregleda ili manjim kirurškim zahvatima.

KLJUČNE RIJEČI: totalna laringektomija, govorna proteza, curenje uz govornu protezu 